\title{
ACTIVITY OF ALDOLASE IN THE COURSE OF EXPERIMENTAL TRICHINELLOSIS IN GUINEA-PIGS
}

\author{
B. KOUDELA \\ Department of Pathological Morphology and Parasitology \\ University of Veterinary Science, 61242 Brno
}

Received March 3, 1983

\begin{abstract}
Koudela B.: Activity of Aldolase in the Course of Experimental Trichinellosis in Guinea-pigs. Acta vet. Brno, 52, 1983; 169-176.

The activity of aldolase was determined in blood plasma and homogenates from the duodenal wall, masseter and heart musculature at different intervals after experimental infection of guinea pigs by Trichinella spiralis larvae. There were significant changes of enzymatic activity in all tissues studied. The dynamics of changes in the course of experimental trichinellosis was closely related to the life cycle of the parasite. The changes were due to altered permeability of cell membranes as well as to mechanical affection of surrounding tissue.
\end{abstract}

Intracellular enzyme, intravital diagnosis, blood plasma, tissue homogenates.

Trichinellosis is generally associated with changes in activity of enzymes; in the blood serum it is increased whereas the enzyme activity in skeletal muscles is simultaneously decreased. The peak of the changes lays in the 4th and 5th week post infection. They are due to enhanced permeability of cell membranes and involve above all cytoplasmic enzymes of low molecular weight. Localisation in the cytoplasm and low molecular weight facilitate the release of enzymes into extracellular space and blood. In the following phase of trichinellosis, the synthesis of muscular enzymes is increased and the permeability of cellular membranes is stabilized within physiological limits (Poznaǹska 1975).

The changes in enzyme activity are not specific for trichinellosis, they occur with different myopathies as well.

Papers concerning enzymes of host infected by $T$. spiralis are mostly casuistic in character and focused on the muscular phase of trichinellosis (Boczon et al. 1969, Kassur et al. 1969, Malik et al. 1960, Poznaǹska 1975, Wišniewska 1969).

Our present trial was based on the assumption that changes in aldolase activity are to be expected not only in the muscular but also in the intestinal phase of trichinellosis.

\section{Material and Methods}

\section{Aldolase activity - determination of physiological values}

The activity of plasma aldolase was measured in 22 guinea-pigs (females, $470-670 \mathrm{~g}$ ). Effects of age, training and food composition on enzymatic activity (Laudahn 1963) were eliminated by selection of experimental animals and husbandry conditions. Blood samples were collected by heart puncture and centrifuged in heparinised tubes at 3.000 r. p. m. for 10 minutes. After blood collecting the guinea-pigs were killed in ether and samples were collected from heart muscles, left masseter and duodenal wall. The tissue samples were thoroughly washed in $0.1 \mathrm{M}$ phosphate buffer and fat and connective tissue were removed. After drying by filtration paper, $200 \mathrm{mg}$ of tissue were cut to pieces of approximately $1 \mathrm{~mm}$. The so prepared tissue was immersed in $10 \mathrm{ml}$ of $0.1 \mathrm{M}$ phosphate buffer and homogenized in a cooled pestle homogenizator for 2 minutes. The centrifugation of homogenates was carried out in a cooled centrifuge at 5.000 r. p. m. for 10 
FIG. I

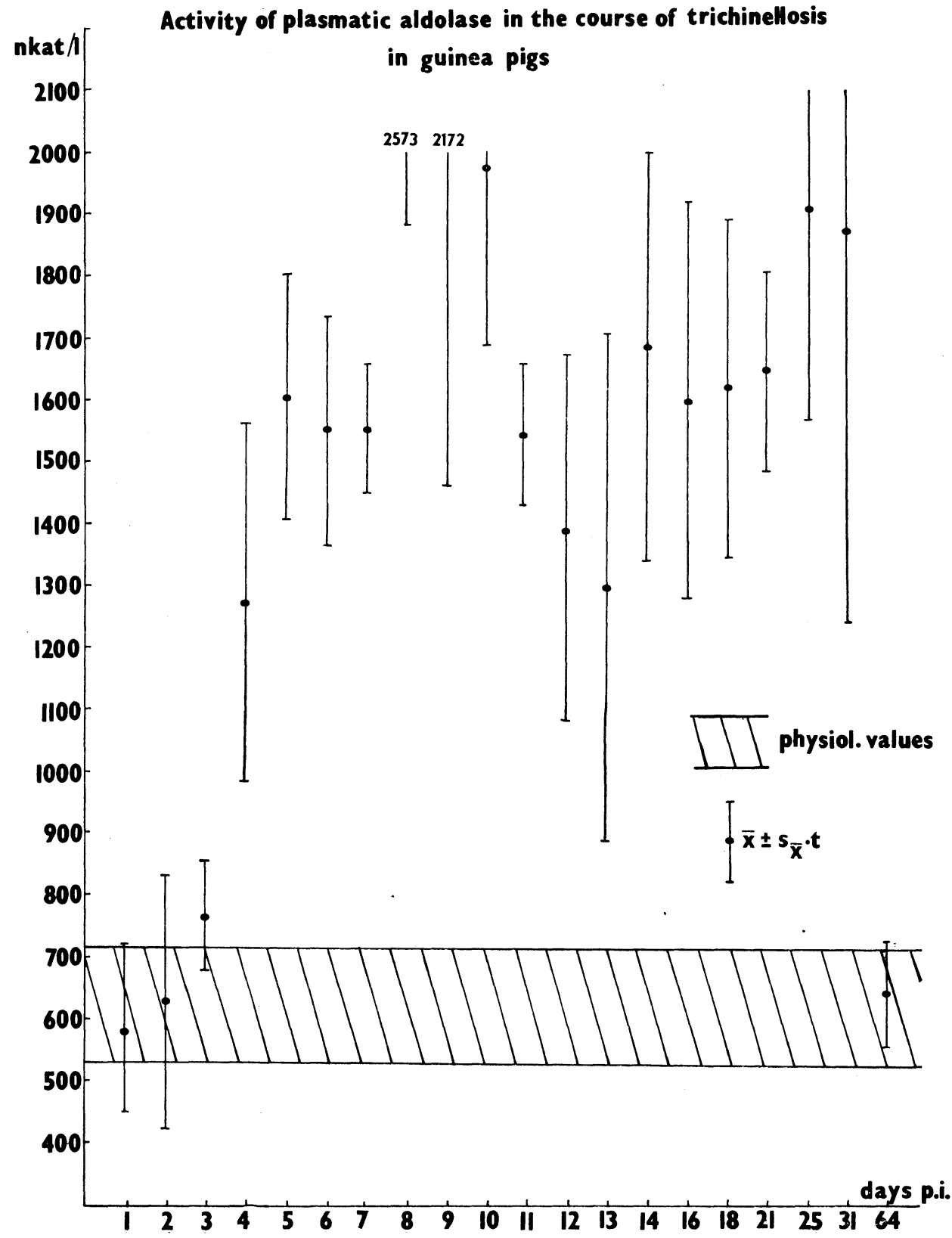


FIG. 2

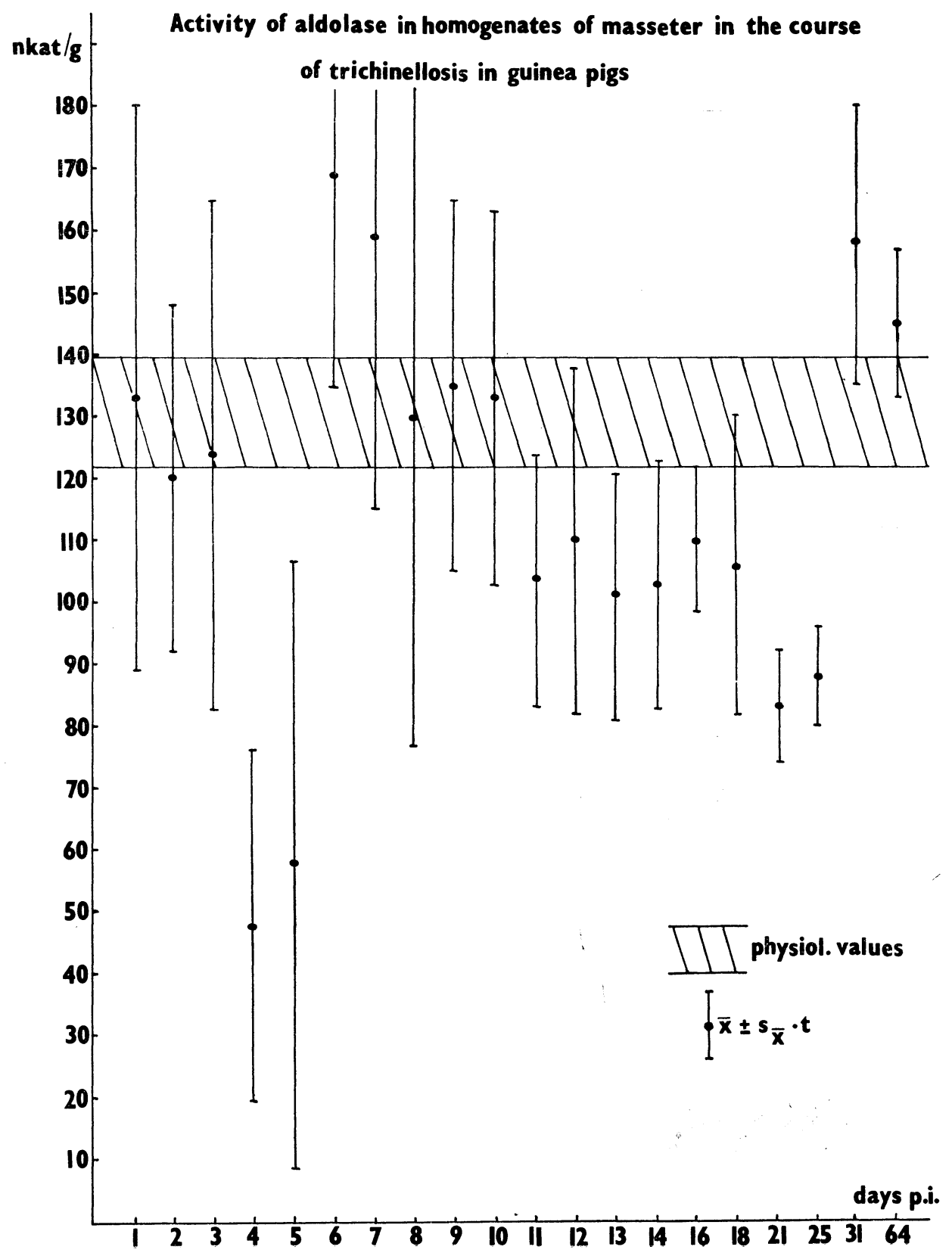


FIG. 3

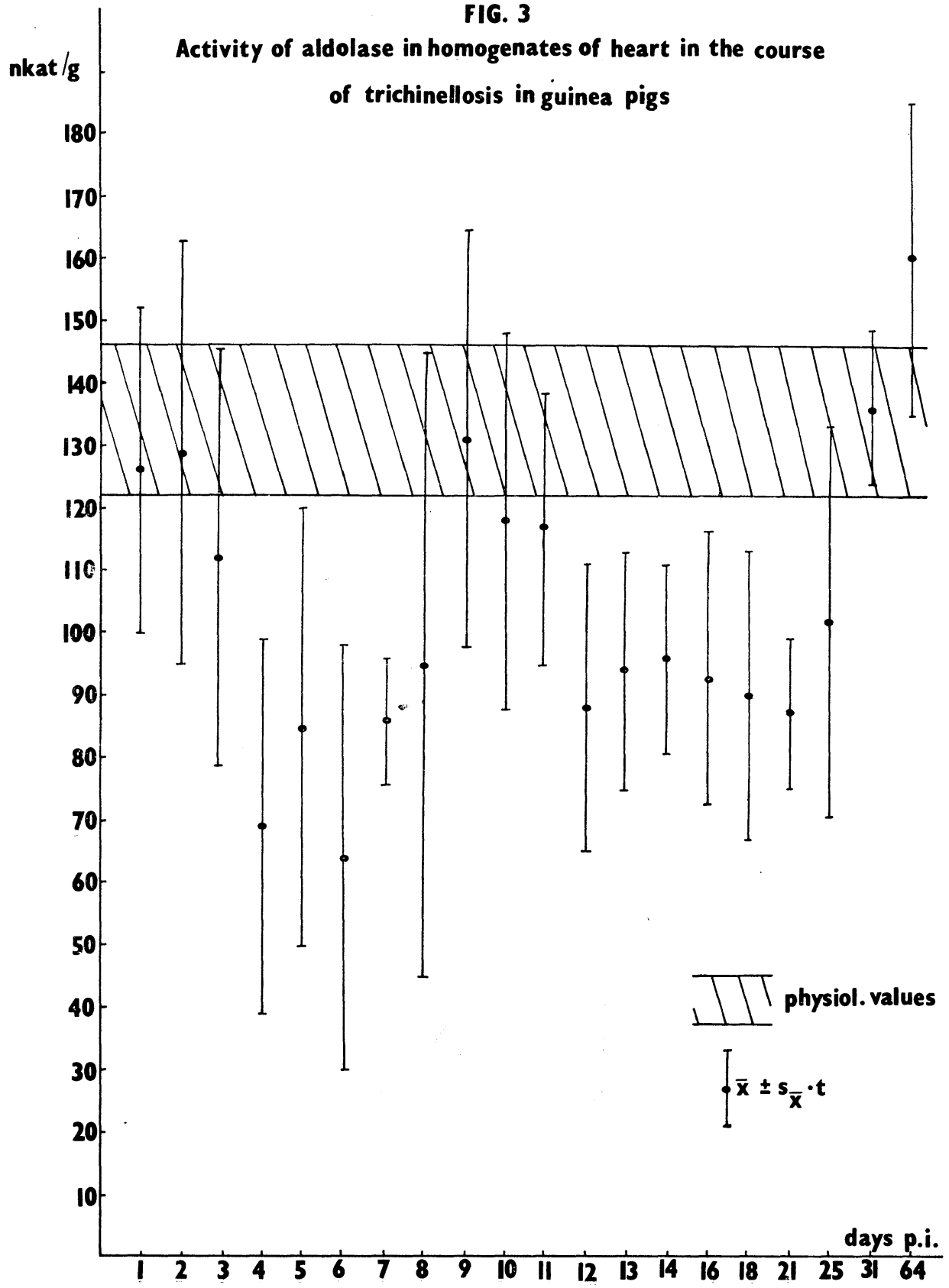


FIG. 4
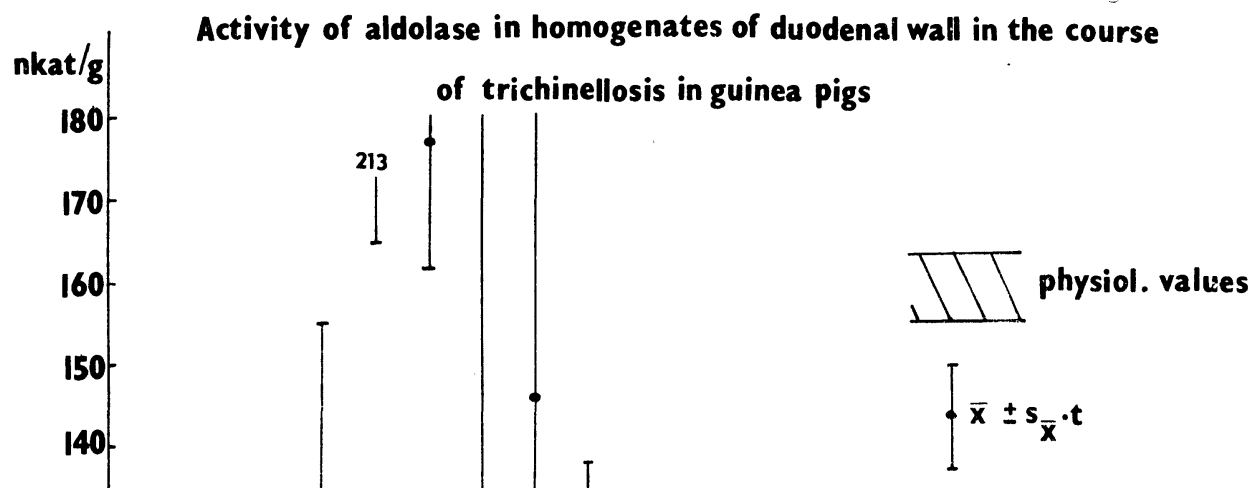
minutes. The supernatant was used for measurements. Enzyme activity was determined by Beck's (1955) method (in Dzúrik 1967). Extinction measurements were performed on a spectrophotometer Varian-Techtron type 635, at $540 \mathrm{~nm}$ and $1 \mathrm{~mm}$-slot. Units of enzyme activity (nkat/liter) were calculated from measured extinctions by means of a calibration graph.

The activity of aldolase in homogenates was related to $1 \mathrm{~g}$ of fresh tissue, as recommended by Lujf (1973).

For the statistical evaluation of results, limits of confidence were calculated.

\section{Aldolase activity - determination in the course of trichinellosis}

A total of 80 guinea-pigs (females, $470-670 \mathrm{~g}$ ), were infected orally by 1.000 larvae each.

Blood and tissue samples were prepared in the same way as with the control group. From day 1 to $14 \mathrm{p}$. i., the samples were collected at intervals of 24 hours, than at days $16,18,21,25,31$ and $64 \mathrm{p}$. i.

The compression method was used for counting T. spiralis larvae in muscle samples.

\section{Results}

The values of enzyme activity of aldolase in blood plasma and tissue homogenates from control guinea-pigs were:

plasma $\quad 615.2 \pm 92.3 \mathrm{nkat} / 1$

m. masseter $131.8 \pm 8.9$ nkat/g of fresh tissue

heart $\quad 134.2 \pm 10.9 \mathrm{nkat} / \mathrm{g}$ of fresh tissue

duodenum $67.2 \pm 5.6 \mathrm{nkat} / \mathrm{g}$ of fresh tissue

The corresponding values in the experimental group are demonstrated in Figures $1-4$.

\section{Discussion}

Our results concerning enzyme activity of aldolase in blood plasma are in agreement with the findings by Bruns and Kirschner (1954) (in Bergmeyer 1974). As for aldolase activity in tissue homogenates from guinea-pig, no data were available.

The tissues for determination of aldolase activity were chosen on the ground of findings about the distribution of $T$. spiralis larvae in intestine and muscles (Dick and Silver 1980; Stewart and Charniga 1980).

We performed no measurements of enzyme activity in isolated larvae. Poznaňska (1975) observed that the low enzyme activity in homogenates from isolated larvae displayed an only futile effect on the activity of enzymes in tissues.

The activity of plasma aldolase increases since day 3 post infection. Poznaňska (1975) reported the highest aldolase activity in the course of trichinellosis in humans in the 4th week p. i. Our results showed the peak of aldolase activity in blood plasma 8-11 days p. i., corresponding to the most intensive migration of the new larval generation in skeletal muscles. Hereafter the aldolase activity declined, remaining, however, $2-3$ times higher than in control animals. Physiological values were attained within 2 months.

In the duodenum, the most elevated aldolase activity was registered by days 5 and $6 \mathrm{p}$. i. when the largest number of new larvae penetrated the intestinal wall. The highest activity in $\mathrm{m}$. masseter was observed by the days 6 and $7 \mathrm{p}$. i., at the beginning of migration of larvae in musculature. By the compression method, the first migrating larvae could be detected at day 8 p. i. 
The decreasing activity of aldolase in the duodenum during the 2nd and 3th week is correlated with the decreasing number of larvae in the intestine (Dick and Silver 1980), the lower aldolase activity in m. masseter corresponds to the smaller number of migrating larvae in skeletal muscles.

In the following phase of trichinellosis, there is an enhanced synthesis of enzymes, probably in consequence of regeneration of the alterated tissues.

From our results it is obvious that the dynamics of aldolase activity in blood plasma and tissues was affected by $T$. spiralis larvae and was closely related to the development of the parasite.

Michejda (1969) and Poznaǹska (1975) considered T. spiralis larvae as ,toxo-allergic agents" alterating the permeability of cell membranes and causing thus the release of enzymes into the extracellular space. Many autors explained also changes in enzyme activity in the course of other myopathies by this mechanism (Laudahn 1968, in Praktische Enzymologie 1968). The changes in aldolase activity observed in the course of experimental trichinellosis in homogenates from the heart, not directly affected by larvae, could, in our opinion, be attributed to this toxo-allergic effect.

Other authors see the reason for elevated enzymatic activity during some myopathies in degeneration and necrosis of muscle fibres (Heyck et al. 1966). Our results as well as morphological studies of different stages of $T$. spiralis by Wright (1979) and Despommier (1976) demonstrated that in addition to the effect on membranous systems the larvae destruct cells and cause consequently a release of enzymes into extracellular space.

\section{Aktivita aldolázy při experimentální trichinelóze morčat}

Po experimentální invazi morčat larvami Trichinella spiralis jsme stanovili aktivitu aldolázy $\mathrm{v}$ krevním plazmatu a homogenátech duodena, svaloviny žvýkače a srdce. Ve všech tkáních vyšetřených $\mathrm{v}$ různých intervalech po invazi byly signifikantní změny $\mathrm{v}$ enzymatické aktivitě aldolázy. Dynamika změn $\mathrm{v}$ průběhu experimentální trichinelózy byla $\mathrm{v}$ úzkém vztahu $\mathrm{k}$ vývojovému cyklu parazita. Př́ícinou změn byly jak poruchy $\mathrm{v}$ permeabilitě buněčných membrán, tak mechanické alterace okolní tkáně.

\section{Активность альдолазы при экспериментальном трихинеллезе} у морских свинок

После эскпериментальной инвазии морских свинок личинками Trichinella spiralis нами определялась активность альдолазы в кровяной плазме и гомогенатах из кишечной стенки, мышечной ткани жевательной мышцы и сердца. Во всех тканях обследуемых в разные интервалы после инвазии животных были установлены явные изменения энзиматической активности альдолазы. Динамика изменений в течение әкспериментального трихинеллеза находилась в тесной связи с циклом развития паразита. Причина изменений сводилась как к проницаемости клеточных мембран, так и к механическим повреждениям окружаюшей ткани. 


\section{Acknowledgement}

We are indebted to Mrs. D. Čechová and Mrs. D. Fáberová for their skillful technical assistance.

\section{References}

BERGMEYER, H. U.: Methods of Enzymatic Analysis. Verlag Chemie Weinheim 1974.

BOCZOŇ, K. - CHODERA, L. - GERWEL, C. - MICHEJDA, J. - WIŠNIEWSKA, M.: Changes in enzymatic activity in course of human trichinellosis. Wiad. Parazytol., 5-6, 1969: 707.

DESPOMNIER, D. D.: Musculature. In C. R. Kennedy (ed.), Ecological Aspects of Parasitology. North-Holland Publishing Co., Amsterdam 1976.

DICK, T. A. - SILVER, B. B.: Intestinal distribution of Trichinella spiralis in rats. J. Parasitol., 3, 1980: $472-477$.

DZÚRIK, R.: Enzymológia. Obzor Bratislava 1967.

HEYCK, H. - LÚDERS, C. J. - LAUDAHN, G.: Beitrag zur Dystrophia musculorum progressiva. V. Mitteilung: Histologische Befunde im präklinischen Stadium der Dystrophia musculorum progressiva, Typ Duchenne. Klin. Wsch., 44, 1966: 813.

KASSUR, B. - JANUSZKIEWICZ J. - POZNANSKA, H.: Some characteristic changes of tissue and serum enzymes activity in experimental and human trichinellosis. Wiad. Parazytol., 5-6, 1969: 706.

MALIK, A. - NIEWIAROWSKI, S. - RACHONं, K. : Elevation of serum aldolase and transaminase level in the course of trichinellosis. Wiad. Parazytol., 4, 1960: 325-328.

MICHEJDA, J.: Problems of the metabolism and ultrastructure of skeletal muscle tissue in trichinellosis. Wiad. Parazytol., 5-6, 1969: 687-691.

LAUDAHN, G. - HEYCK, H.: Fermentaktivitätbestimmungen in der gesunden menschlichen Muskulatur und bei Myopathien. I. Enzymmuster und intracelluläre Verteilung von Enzymen im gesunden Skelettmuskel. Klin. Wschr., 41, 1963: 493.

LAUDAHN, G.: Enzyme im Serum bei Muskelkrankheiten. In: Praktische Enzymologie. (Schmidt F. W., Hrgs.) Bern-Stuttgart: H. Huber 1968.

LUJF, A.: Veränderungen von Muskel- und Serumaktivitäten bei Erkrankungen menschlicher Skelettmuskulatur. Beilage zu Wien. klin. Wschr. 85, 1973, Heft 5.

POZNANSKA, H.: Mathematical interpretation of tissue - serum enzyme activity relation in trichinellosis. Wiad. Parazytol., 4-5, 1975: 689-701.

STEWART, G. L. - CHARNIGA, G. L.: Distribution of Trichinella spiralis in Muscles of the Mouse. J. Parasitol., 4, 1980: 688-689.

WISNIEWSKA, M.: Some data of the diagnostic value of creatine kinase in human and rat trichinellosis. Wiad. Parazytol., 5-6, 1969: 711.

WRIGHT, K. A.: Trichinella spiralis: An Intracellular Parasite in the Intestinal Phase. J. Parasitol., 3, 1979: $441-445$. 